\title{
On Werner Herzog's Documentary Grizzly Man: Psychoanalysis, Nature, and Meaning
}

\author{
John W. White
}

\section{Introduction}

Few documentaries in recent years have received as much acclaim as Werner Herzog's film Grizzly Man (2005), a narrative exploration of the life and death of amateur grizzly bear expert and wildlife preservationist Timothy Treadwell, who supposedly lived unarmed among grizzlies for 13 summers before being eaten alive by one. It won the Alfred P. Sloan award at the 2005 Sundance Film Festival and was awarded Best Feature Documentary at the Mountain Film in Telluride Festival. Ebert and Roper have given it "two thumbs way up" and J. Hoberman of The New York Times has called it "one of the most remarkable documentaries produced by any filmmaker in recent years." However, like many of Herzog's previous films, it has also generated a certain uneasiness and even minor controversy, as reflected in several online reviews. One critic, commenting on the "myth of objectivity" which surrounds the genre of documentary, prefaced his review by noting that it was personal movie making rather than "the typical PBS/Discovery Channel sort of informational objectivity." [2] Another commented that he had mixed feelings and was left with the impression of opportunism rather than inspiration on Herzog's part and felt "somewhat manipulated."'3] Herzog's filmmaking has always been controversial (Bachman 1977; Gitlin 1983; Cronin 2002; Prager 2007), but the subject matter of this particular feature may well stir more interest among members of the American public than his past films.

My own interest in Grizzly Man as subject matter is largely cultural, as this contributes so heavily to the perspectives by which we interpret a myriad of phenomena. Herzog being a German director narrating the life of Timothy Treadwell—whose personage is unmistakably the goofy American surfer dude-means a GermanAmerican transatlantic interchange in the form of a cultural production which lies somewhere between cinematic art and a sort of public discussion of an intellectual bent.[4] Given that within the history of the German tradition so many of its artists have lived outside of Germany, the fact that Herzog has lived in California for many years does not alter the fact that he was born and raised in Bavaria and more importantly, that his background is rooted in the German tradition. Thus, the reason he offers for his interest in Treadwell as subject matter-that he himself had filmed in the wilderness of jungles - does not suffice. Were it not for his given name and accent, for certainly his proficiency in English must be commended, the viewers might assume his background to be all-American. However, it is unimaginable that the German literary, painting, and intellectual tradition did not play a large role in forming his perspective toward Treadwell (Cronin 2002:136-137, 140; Prager 2007:3-5, 76-81). His deemphasizing his ties to the German tradition in Grizzly Man is understandable to a certain extent. Americans have always tended to be suspicious of European complexes of superiority; given that part of history's burden entails the complex relationship between the social function of artistic traditions and varieties of nationalistic sentiment, this was perhaps prudent. Many American viewers, however, are exposed to certain elements of the aforementioned German tradition filtered through Herzog's narration, when, as I will argue here, perhaps Herzog might have done better to learn from American pragmatism in order to gain a more balanced perspective and also from European and American scholars 
who have been formed in the European Continental Tradition.

Cultural perspectives influence psychoanalysis, nature, and meaning quite decisively. First, any narrative on the Treadwell story_-including that co-written by Treadwell himself_-or here, commentary thereto, is going to necessarily carry some psychoanalytic value. There are many different angles by which to view persons in a given situation, as they play the roles of the analyst and the analysand, the terms and conditions of the act of analysis itself, and the social context in which such analysis takes place, or to enunciate this last issue more precisely, the certain matrices of social (and to that extent, historical) power with which psychoanalysis remains inexorably enmeshed. Next, there is the matter of environmentalism and the many debates which have taken place within environmental studies, such as the extent to which external nature is a type of anthropomorphism, or as such, subjectively constructed. Then there is the question of meaning, to which the documentary as a narrative act is quite central, and of whether meaningful narration can proceed in the absence of dialectical reflection upon the situation. These three elements, perhaps rarely discussed in such a way as to aim at any sort of synthesis, converge in Grizzly Man. As will be demonstrated in the space below, Herzog's background and knowledge of the German tradition informs his method of analyzing Treadwell and in certain respects accounts for its inadequacy, as he remains confined by a paradigm of thought originating in German classicism which endeavors to "superegoize" the analysand rather than to explore possibilities of experience. The conception of nature which Herzog posits seems to have been conceived during his earlier years in reaction to natural sentimentalists; however, it is extreme, and its consequences seem not to have been critically thought through. In the first part of this essay, I will attempt to summarize Grizzly Man, for the purposes of the discussion outlined above, with an emphasis on Herzog's introduction. This summary will then serve as a sort of "backdrop" against which to discuss Herzog's use of psychoanalysis, his theory of nature, and his sense of meaning.

\section{Herzog's Introduction of Timothy Treadwell}

Since Herzog's films are written to resemble dreams (Cronin 2002:65), it is difficult to mark exactly where the introduction ends and the film proper begins. I consider the first three of the film's 27 chapters as providing pertinent information for the understanding of the story, and the next two chapters thereafter as part of the film's commencement. The opening is set in the wilds of Alaska, with Treadwell, wearing an exaggeratedly large black jacket and sunglasses in front of the camera, squatting, in front of two large bears. While his proximity to them is not terrifyingly close, neither does his lack of distance convey any sense of carefree relaxation. In the case that some readers have not yet seen the film and may therefore require some direct citation in order to gain some preliminary understanding of the star of the documentary, I will quote Treadwell at length as he gives a synopsis of his situation:

I'm out in the prime cut of the big green. Behind me is Ed and Rowdy, members of an up-and-coming subadult gang. They're challenging everything, even me. Goes with the territory. (On the screen appears “Timothy Treadwell, 1957-2003.") If I show weakness, if I retreat, I may be hurt, I may be killed [...] For once there is weakness, they will exploit it, they will take me out, they will decapitate me, they will chop me into bits and pieces. I'm dead. But so far, I persevere, persevere. Most times I'm a kind warrior out here [...] No one ever friggin' knew, that there are times when my life is on the precipice of death, and that these bears can bite, they can kill. And if I am weak, I go down. I love them with all my heart, I will protect them. I will die for them, but I will not die at their claws and paws. I will fight, I will be strong, I will be one of them. I will be ... the master. But still a kind warrior. (He kisses his palms, then raises and opens them in the air.) I love you Rowdy. Give it to me baby. That's what I'm talking about (he repeats this last sentence twice). I can smell death all over my fingers (Herzog 2005).

Thereafter, various shots of bears roaming around a large plain are shown and the sound is filled with ruggedsounding music from an electric guitar, rife with string-bending and feedback with medium distortion. I'll likewise cite Herzog at length, as he makes his first statement, and introduces himself:

\footnotetext{
All these majestic creatures were filmed by Timothy Treadwell who lived among wild grizzlies for 13 summers. He went to remote areas of the Alaskan peninsula believing that he was needed there to protect these animals and educate the public. During his last five years out there, he took along a video camera and shot over 100 hours of footage. What Treadwell intended was to show these bears in their natural habitat. Having myself filmed in the wilderness of jungles I found that beyond the wildlife film, in his material lay dormant a story of astonishing beauty and depth. I discovered a film of human ecstasies and darkest inner turmoil. As if there was a desire in him to leave the confines of his humanness and bond with the bears, Treadwell reached out, seeking a primordial encounter. But in doing so, he crossed an invisible borderline (Herzog 2005).
} 
He follows this by showing more scenes shot by Treadwell, this time of him coming within much closer proximity of the bears, so close, that he has physical contact with them. He shows one particular bear standing on two legs, scratching his back against tree limbs. After the bear leaves, Treadwell approaches the tree. Although Treadwell wears sunglasses, the viewers have no difficulty perceiving his amazement with what he has witnessed. He modulates his voice in such a way as to sound ridiculous, exclaiming, "He's a big bear!" over and over again. Herzog then discusses Treadwell's excitement and how well this connected him with children against a backdrop of photographs and drawings, presumably from some of the children he'd visited. In hopes to create awareness, Herzog relates, Treadwell talked to thousands of school children, many of whom would later recall his "fabulous storytelling" as one of the most memorable events of their school years. Additionally, he took his mission so seriously that he never solicited for a fee. "Over time," relates Herzog, "he reached the status of a national celebrity." Herzog then shows a clip from an interview with Keith Morrison, which aired on Dateline NBC, "Timothy Treadwell is crazy about bears. How crazy?"[5] Herzog goes on to claim, "It was as if he'd become a star by virtue of his own invention." Just past the third chapter, Herzog provides more information about the story, such as that his girlfriend, Amie Hugenard, died by his side. Herzog also shows aerial footage of the wilderness scene where much of the Herzog's story of Treadwell takes place, Katmai National Park, Alaska. He goes on to include a statement rather pertinent to the viewer's understanding of the plot. "Treadwell saw himself as the guardian of this land and stylized himself as Prince Valiant, fighting the bad guys with their schemes to do harm to the bears. But all this land is a federally protected reserve" (Herzog 2005).

\section{Reconstructing Treadwell: Interviews and Inner Being}

A good nature program, Mike Lapinski has noted (2005:15), requires the following ingredients: a charismatic lead character, an interesting story, and beautiful scenery with wildlife. Herzog has all of these and he goes back and forth between the Alaskan wilderness and interviews with those who knew Treadwell in locations as far away as California and Florida, as he seems to piece the mystery together. Here I will cite some of the information Herzog was able to collect as I summarize the story. One of Herzog's first interviewees, Sam Egli, worked on removing Treadwell and Hugenard's remains, which, as he testifies, amounted to four large garbage bags. Treadwell, he says, probably meant well and in a way tried to help the resource of the bears. "But to me he was acting like he was working with people wearing bear costumes instead of wild animals ... He got what he deserved, in my opinion." He supposes that the only reason why he lasted as long as he did was because the bears may have considered him afflicted, "like he was mentally retarded or something" (Herzog 2005). To him, it looked as though Treadwell believed that the bears looked frightening, but were harmless creatures, which he could approach, pet, sing to, and bond with, like they were "children of the universe or some odd [sic]."[6] Brad Prager, also citing this interview (2007:86), contends that although this may seem cruel, Egli is hardly alone in thinking this way. Herzog then interviews a couple who knew Treadwell, Marc and Marie Gaede. Marie quotes from one of the last letters she received from Treadwell, in which he declared the exigency of his mutating into a bear to handle the life he led. She explains how this is a religious experience. Marc reads from one of many vitriolic letters he has received, demonstrating the resonance that Treadwell and his activities carried into the realm of the political: "A bear diet consists of liberals and dems and wacko environmentalists that think that the spotted owl is the most important thing in the world. We need to somehow drastically increase the number of bears in America, especially in such key spots as the Berkeley campus" (Herzog 2005).

Larry Van Daele, a bear biologist, discusses the manner in which Treadwell wanted to become a bear. He notes having spoken with those who had encountered him in the field, and watched him act like a bear, "woof(ing)" at them, and acting in the same way that a bear would upon being surprised. Van Daele chooses not to suppose the reason for Treadwell's behavior; he offers a conjecture, however, asserting that upon spending days in the field with the bears, a certain siren song comes calling, which can induce one to want to spend more time in their simpler world. He then draws a distinction between illusion and reality, which Herzog will grasp as being central to the situation, the former being that it seems to be a wonderful world, and the latter being that the world of the bears is actually quite harsh, and that humans can never enter that world for being different.

Herzog defends Treadwell not as an ecologist, but rather as a film maker. He notes how methodical Treadwell is, taking some shots up to fifteen times, and shows examples of this. Still, during a scene in which Treadwell has 
been filming himself and has left the camera for a moment, Herzog comments on the shot of bare nature, the wind blowing the brush, lamenting that in all of Treadwell's excitement, he seems not aware of the beauty that nature can have, should one slow down and take the time to admire it. Herzog then explores Treadwell's soul, based, of course on Treadwell's own speech before the camera, which, he explains, “... was his instrument to explore the wilderness around him, but increasingly it became something more. He started to scrutinize his innermost being, his demons, his exhilarations. Facing the lens of a camera took on the quality of a confessional" (Herzog 2005).

In one scene, Treadwell seems to aver his agnosticism, but argues that if there's a God, then God would be very pleased with him. Then he supposes how it would be, if God could watch how much he loves, adores, and respects the animals, and how he is "one of them." Moreover, he aggrandizes himself before a supposed almighty, in regard to the altruism of his traveling around the world to show his research for no charge. Of this work he says, "I feel good about myself doing it. And I want to continue, I really hope I can. But if not, be warned. I will die for these animals." He repeats this last sentence twice. "Thank you so much for giving me these animals, for giving me a life. I had no life. Now I have a life." Next, Herzog shows a clip in which Treadwell, simultaneously walking and filming himself, discusses his failed relationships with women. Treadwell seems perplexed by his failure to build lasting relationships, given his nice personality. "I'm fun," he claims, "I'm very, very good in the-You're not supposed to say that when you're a guy. But I know I am. They know I am. And... I don't fight with them, I'm so passive. Bit of a patsy!" He asks himself whether this is a turnoff to girls. Admitting that he is not a "total great guy," he nonetheless asserts that he has a "good life going." For awhile he laments the fact that he is not gay, going into graphic detail about what he presumes gay life entails, but then returns to how he loves girls, who, he adds, need a lot more care and finesse, which he says he likes "a bit." He then attempts to discuss the experience of "when it goes bad and you're alone," but cuts himself short. Presumably, his mind is too weak for a deep self-analysis, and the viewers learn that his lamentation over not being gay derives from his belief that rebounding is much more difficult for heterosexuals. Nonetheless, he offers a disclaimer, that he is sure that gay people have problems as well, but just not as much as "one goofy straight guy named Timothy Treadwell“" (Herzog 2005).[7]

Following this, Treadwell is shown lying on the ground, propping himself up on one elbow and speaking to a fox, which he has named "Iris." He asks the fox how he came into this work, that is, whether or not the fox had ever heard the story. He confirms that he was troubled, and that he drank. He intimates that the fox wouldn't know what that is. He tells of how experience with alcohol addiction reached a point where he would either die or break free of it. After programs could not help him, he discovered "this land of bears." He then realized that they were in peril, and that they needed a caretaker, but not a "person messed up." He continues, "So I promised that if I would look over them, would they please help me to become a better person and they've become so inspirational ... I gave up the drinking. It was a miracle." This is not the last time in which he refers to certain events in terms of the miraculous. Then, from high altitudes Herzog shows footage of a region of the glacier, saying:

In his diaries, Treadwell often speaks of the human world as something foreign. He made a clear distinction between the bears and the people's world which moved further and further into the distance. Wild, primordial nature was where he felt truly at home. We explored the glacier of the back country in the Grizzly Sanctuary. The gigantic complexity of tumbling ice and abysses separated Treadwell from the world out there. And more so, it seems to me that this landscape in turmoil is a metaphor for his soul (Herzog 2005).[8]

To find why Treadwell went into the wild, Herzog visits the former's parents, Val and Carol Dexter. He explains to the viewers of Treadwell's childhood in Long Island, where his father worked as the foreman of a construction team for a telephone company. "There must have been an urge to escape the safety of his protected environment." He learns that nothing in Treadwell's childhood pointed to anything extraordinary and that he was a good kid, not an "A" student, a "B" student, and that he got along well with kids and animals. As a child, he had a pet squirrel, named Willie, and developed into an all-American boy. His parents tell of him going off to Bradley University on an athletic scholarship, drinking, hanging out with the wrong crowd, injuring himself, thus losing his scholarship, and coming back home. He wanted a new start, so he went out to California when he was 19 or 20. He got a job, hired an agent, and changed his name to Treadwell (a family name), attempting to be theatrical. He had been on Love Connection, and allegedly, he came in second to Woody Harrelson trying out for the bartender on Cheers, and thereafter he spiraled down. Herzog then questions a friend in California, which brings the viewer more information on Treadwell's cycle of drugs, epiphanies, and the need to create a new persona for himself, sometimes fabricating wild stories. He interviews former co-worker and girlfriend Jewel Palovak, who discusses how troubled he was, including his highs and lows, confirming that he certainly had a dark side. "He was mixed up in drugs, which makes 
you mixed up in bad people, people with guns. Timothy always had a sense of justice that was his own." When Herzog asks her how dangerous, she tells a story of their going to the Van Nuys courthouse to watch people being sentenced, but she believes that he did so to remind himself what his life would be like if he went to that dark place (Herzog 2005).

Herzog then flashes to Alaska, where Treadwell stands before a camera, mawkishly repeating, "I'm in love with my animal friends." In another scene he handles some feces from a bear he had named "Wendy," ecstatic that it is still warm. Treadwell asserts that everything about them is perfect. At first using free-indirect style, Herzog narrates: "Perfection belonged to the bears. But once in a while, Treadwell came face-to-face with the harsh reality of wild nature. This did not fit into his sentimentalized view that everything out there was good and the universe in balance and harmony." Herzog then explains why male bears sometimes kill cubs — to fornicate with the mother-and shows a shot of a young bear's forearm and paw, with Treadwell's hands holding the paw. Then he shows another scene, this time of Treadwell sitting next to a carcass of a young fox. "I love you and I don't understand. It's a painful world." Herzog counters with his conception of nature: "Here I differ with Treadwell. He seemed to ignore the fact that in nature there are predators. I believe the common denominator of the universe is not harmony, but chaos, hostility and murder" (Herzog 2005).

Herzog represents Treadwell's paranoia quite well. He presents one instance where some tourists throw rocks at one of Treadwell's friends (a bear), and points out that for all Treadwell's vehement rhetoric against poaching, this is the most damage to the bears that he has been able to film. In one instance, Treadwell, finds a rock on which, presumably, tourists have left him a note that reads, "Hi Timothy, see you in summer 2001." Treadwell sees this as a warning, as "some sort of a haha." When it appears that someone has drawn a "smiley face" on a rock near his camp site, he also considers it "Freddy Krueger creepy." Herzog relates that there were visitors now and then, but emphasizes that for Treadwell there were just intruders, an "encroaching threat upon what he considered his Eden." In a chapter titled "Park Rant," Herzog shows Treadwell at the end of his 2001 expedition, during which he had violated Katmai National Park rules by not moving his camp site often enough and by not maintaining enough distance from the bears. Building up a rage which the director describes as "almost incandescent, artistic," Treadwell rebukes the Park Service and boasts of his having protected the bears, despite the fact that the government (here he means Park Service) has flown over twice in two months. Repeating himself for effect, he asks how they dare challenge him and smear him with their campaigns. "I will continue to do this," he vows. "I will fight them. I will be an American dissident if need be. There's a patriotic time going on right now, but as far as this (expletive) government's concerned ... (more expletives). Lowering the sound of the eco-warrior's voice, Herzog explains, "Now Treadwell crosses a line with the park service which we will not cross. He attacks the individuals with whom he worked for 13 years." Herzog continues:

It is clear to me that the Park Service is not Treadwell's real enemy. There's a larger and more implacable adversary out there, the people's world and civilization ... The actor in his film has taken over from the film maker. I have seen this madness before on a film set.[9] But Treadwell is not an actor in opposition to a director or producer. He's fighting civilization itself. It is the same civilization that cast Thoreau out of Walden and John Muir into the wild (Herzog 2005).

After showing those closest to Treadwell scattering his ashes near Hallo Bay, Alaska, bringing some amount of closure to the pain of their loss, Herzog finally draws the documentary to a close, but not before visiting the location of Treadwell's death. Reviewing footage shot right before his death, he zooms in on one bear's face, commenting that what haunts him is that in all the bears Treadwell has filmed, "I discover no kinship, no understanding, no mercy. I see only the overwhelming indifference of nature." He avers that for him no such secret world of the bears exists. Closing, Herzog shows footage of bears running, footage that is partially obscured by both distance and fog. He discusses how the argument as to how wrong or right Treadwell was "disappears into a distance into a fog." It is his footage that remains, he contends, "And as we watch these animals in their joys of being, a thought becomes more and more clear. That it is not so much a look at wild nature as it is an insight into ourselves, our nature. And that for me, beyond his mission, gives meaning to his life and to his death" (Herzog 2005).

\subsection{The German Tradition: Experience, Psychoanalysis, Animals}

The sort of psychoanalysis I discuss here may require some explanatory remarks. One rather laudable aspect of Herzog's representation of Treadwell's psychic being is that the Bavarian director never interviews such would-be authorities as psychologists or psychiatrists to assign Treadwell a certain congenital condition or render otherwise "essentialist" interpretations. In fact, while Herzog sees Treadwell as troubled, he remains unconvinced that Treadwell 
was insane.[10]

Rather than referring to any sort of neuropathic dysfunction, he very often refers to Treadwell's "soul" and battling his demons. It is important to remember that German uses one word, Geist, for what in English might be alternately termed soul, spirit, or mind. Thus, Herzog's conception of the psyche is much more anthropomorphic, such as the original Greek term suggested, being bound up with the idea of human consciousness, which is also how Sigmund Freud considered the psyche and defined his work against American behaviorism (Freud [1940] 1969:28n). Long before Freud, however, the German literary tradition had been experimenting with core concepts of psychoanalysis since the era of Goethe, considered within German studies the age of classicism. Admirers and critics of Freud have noted that Goethe did have an immense impact upon the former (Gay 1988:128, 366, Deleuze and Guattari [1972] 1983: 55, 118). Given that psychoanalysis in the German tradition was born out of the literary narrative, for Herzog to play the role as analyst is nothing extraordinary.

Now, there are two very important aspects to consider when examining Timothy Treadwell: first, as a college dropout, he endeavors to become a bear expert, conducting field "research" (Herzog 2005, Treadwell and Palovak 1997) and wishes desperately to gain the respect of the scientific community (Lapinski 2005:21-22); and second, he seeks to escape his prior social positioning by an attempt to journey into "the secret world of the bears." He believes that his having "the heart of a wild animal" (Treadwell and Palovak 1997:1) can compensate for his lack of education and training (Bildung). To Herzog, the problems with this must be immediately recognizable: ever since Goethe, subsequent writers have had to confront a certain mindset, which privileges the notion that one should know one's place in respect to the general order of society, and ought not ethereally venture to experience beyond that, especially when one is presented with an opportunity to take a short cut in order to arrive at a higher station. He argued that "everything that liberates our mind without at the same time imparting self-control is pernicious" and lamented that "there are many people who imagine that what they experience they also understand" (Goethe 1998:67,117).

Thoughts such as these were the driving force behind the moral lesson of his poem The Sorcerer's Apprentice (Der Zauberlehrling), the story of the young apprentice upon which Mickey Mouse's character in the Disney cartoon film Fantasia is based. Here, the apprentice's desire to command the broomsticks to move according to his own will leads him to attempt to cast a spell as a means to that end, despite the fact that his master has admonished him not to do so. When he cannot remember the last line of his verbal formula, events take an unexpected and chaotic turn, eventually forcing him to concede the recklessness of his actions.

These views also contribute to the moral lesson of Faust I, the story of the alchemist and doctor whose aspirations to become godlike lead him to dabble in magic, and whose desire to experience that ethereal sphere beyond the ordinariness of human existence, leads him to the near destruction of a young woman with whom he falls in love. The German critic Erich Trunz has argued that in Faust lies a certain longing (Sehnsucht) to reach over the boundaries of his ego, and this longing rushes him to reach out of his element, mixing up that which is high and that which is low, entangling him increasingly deeper into the underworld (1998:483). However, Faust's antagonist Mephistopheles, a figure kin to the devil, first appears to him in the form of a black dog, running around, out of control. For Goethe self-control in social relations was so essential to being human rather than animal (151) that he could, as the German critic Hans Mayer has pointed out ([1946] 1974:271), be quite hard and merciless toward those who lacked this quality, as he was to his one-time friend Jakob R. M. Lenz, after the latter had fallen mad, full of whimsical behavior and mistrust, desiring to experience beyond what he was able to understand. An admirer of Anaxagoras' teaching that animals have active but not passive reason, which serves as the interpreter of understanding (151), Goethe seems to have recognized Lenz' loss of this reason and seems to have been either incapable of or unwilling to help him regain his humanity.

Georg Büchner would somewhat sympathetically explore Jakob R. M. Lenz in his novella based on the man's decline. Interviewed by Paul Cronin (2002:137), Herzog names Büchner among authors whose works he "can only speak of in awe" and once used an adapted version of Büchner's play Woyzeck for his 1976 eponymous film starring Klaus Kinski (Herzog [1976] 2000).[11] More recently however, it has been pointed out that this period for Herzog was fleeting; soon thereafter the film director came to "distance himself from most shared ground with traditional leftist ideas" (Prager 2007:78). Büchner's literature reflects his own struggle for political freedom during the 1830s (Mayer [1946] 1974), before the terms "left" and "right" became such a part of the political nomenclature, but he is highly regarded in progressive circles. However, it is the figure of Lenz which facilitates an analysis of Treadwell, although, it has been shown that Woyzeck and Lenz seem quite similar in their relative social powerlessness (Larsen 1988). Although short passages provide rather quaint impressions, the following citations show some similarity between Büchner's Lenz and Treadwell: 
...Lenz went through the mountains. The peaks and high slopes in snows, gray rocks down into the valleys, green fields, boulders and pine trees. It was cold and damp, water trickled down the rocks and sprang over the path. Pine branches hung down heavily into the moist air. Gray clouds moved across the sky ... pain tore through his chest, he stood, panting, his body bent forward, eyes and mouth wide open, contain all within him, he stretched out and lay over the earth, he burrowed into the cosmos, it was the pleasure that hurt him (Büchner 1986:139-140).

The rush of the face-to-face encounter (with "Mr. Chocolate" bear) lifted me into a euphoric state. I practically flew back to my campsite, dancing a jig and throwing my arms into the air. When I arrived at the raging river, another transformation occurred. I no longer feared the rapids. The river still warranted my caution and respect, but not my cowardice. Summoning the power of the grizzly within me, I dove in and paddled vigorously across, snarling and growling the whole way. I was wild and free (Treadwell and Palovak 1997:29).

Lenz is a character whose ego and reality-consciousness are lost, whose tendencies toward the schizophrenic eventually become rather strikingly manifest (Wittkowski 1978:344; Jancke 1979:242-245). Lenz obtains his joy in life from traversing the natural landscape, but this bonding with nature comes at the cost of remaining alienated from the normal world of human relations. He cannot be persuaded to return to his family, averring that without being able to enjoy nature, he would go mad. But while Lenz relishes in being one with nature while impervious to normal human relations, to bond with or otherwise "become" a certain species of animal never occurs to him.

The desire to experience the perspective of the animal is more apparent by late nineteenth century. One memorable essay by Nietzsche extols the virtues of animals: "Consider the herd grazing before you. These animals leap about, eat, rest, digest, and leap again; and so from morning to night and day to day, only briefly concerned for their pleasure and displeasure, enthralled by the moment..." ([1874] 1993:8). Nietzsche notes the contradiction of man's pride in being human rather than animal, and man's envy at the happiness of the animal.[12] But it should be made clear that Nietzsche comes to understand that the aspiration toward animal instincts should not signify escapism or weakness; rather, that these are bound up with the will to power (1913:110). Recently, Monika Maron, an East German author, offers a more in-depth picture of the desire to experience being animal, in her Silent Close No. 6 (Stille Zeile Sechs).[13] Her anti-heroine, Rosalind Polkowski, is a discontented journalist who is hired by a retired Communist Party leader, Herbert Beerenbaum, as an amanuensis, to record his memoirs. Her moral consciousness has problems with the idea. She is tactile, capable of feeling vibrations of the old man's angry body as these penetrate her flesh down to her heart (Maron 1993:12-13). She also tends to blend the concrete and the abstract, considering both "freedom" and "a human being" to be a "place" and believes that "we all have to be plant, animal, and human" but she finds it difficult to decide on the order $(66,70)$. In one scene near the beginning of the story, she takes pity on a neighborhood cat and decides to give the cat the sausages that she had been saving for her dinner (15). At another point she asks Beerenbaum whether he really believes that generations of people would be born so that Communists can test their ideals on them, and she avers that her ideal "is to be a cat, as they are not subject to Communists or anyone else" (135).

Despite their shared idealization of being animal — a notion at which humanists of all sorts bristle-there is one very important difference between the figures of Rosalind Polkowski and Timothy Treadwell. Rosalind has been able to rather solidly connect her ideal of being an animal to the fact of her living in an oppressive, male-dominated, single-party sociopolitical order. She is painfully aware that she enjoys no means by which to assert her voice and is therefore excluded from the political process. But whereas Rosalind kept company with those whose views were out of sync with the Party line, Treadwell does not seem to have associated with serious political dissidents. And while, as we have seen, he claims that as a child he had the heart of a wild animal, he might have come into contact with people who could have helped him understand himself in terms of the social and also channel his energies in a positive direction, had American middle class society been able to witness real improvements in their social system. Those who most daringly ventured toward such change, however, were either assassinated, such as Martin Luther King, Jr., John F. and Robert Kennedy, or were otherwise marginalized, while the war in Vietnam, an influx of drugs, and subtler means of ethnic/racial bigotry served to distract from such ideals, creating instead a general climate of chaos, instability and fear. Less than ten years after two of the aforementioned assassinations, which occurred during Treadwell's preadolescence, the nation's elite began testing many of the policies that would later become the staples of Reaganomics on the City of New York (Harvey 2005:46-51). Rarely can suburbia insulate itself from the problems associated with an abused and demoralized working class in the inner city, and one can assume that as a youth, Treadwell must have been indirectly affected. In his research, Mike Lapinski interviewed a fellow diver at Bradley, who recalled Treadwell as "always ready to fight...” (Lapinski 2005:92).

One of the most problematic aspects of Herzog's narration is that only once does he come close to inquiring 
into Treadwell's lived experiences, particularly violent ones, which for most people would be rather traumatizing and which are symptomatic of so many communities in New York, southern California, and many other regions. The introduction to Treadwell's biographical writing is revealing: "I landed in Long Beach, California, an overactive street punk without any skills, prospects, or hopes. What little assets and attributes I possessed were quickly devoured by a voracious drinking problem. Alcohol soon gave way to drugs" (Treadwell and Palovak 1997:2-3). He then tells of a downward turn: "I medicated myself with lines of cocaine, buckets of booze, and sprinkled in the new thrills of crystal meth and Quaaludes. Incidents of madness and danger occurred with frightening frequency." He then goes on to tell a story of an altercation one night with a drug dealer named Turk, which started when Turk accused Treadwell of being a "maggot hanger-on type" and made other demeaning statements:

I kicked my tennis shoe into Turk's smug face, knocking him backward into an expensive antique hutch. Fine china avalanched to the ground, some cracking over Turk's bloody mug. The other three dope dealers lit into me. None of them was much bigger than me, but they were tougher than nails. They punched and slapped me, then flung me headfirst into a wall. Curiously, my head went through the wall, and I was suddenly gazing into the kitchen. Dazed, I looked around, momentarily awed by the shiny, well-appointed room. Meanwhile, the dopers were still in the dining room, with the rest of my body, kicking and striking me... Growling, I extricated my torso, and began spinning around like a top (Treadwell and Palovak 1997:3).

This is fabulous story-telling, embellished with imagery that may invoke episodes of The Three Stooges and animated cartoons. While Herzog discusses the content of Treadwell's diaries for factual information, he ignores Treadwell's book, and foregoes any deep investigation into the sources of trauma in Treadwell's lived experience, meanwhile demonstrating that Treadwell often fabricated stories. Nonetheless, I would not condone simply dismissing Treadwell's narration on the basis that neurotics fabricate, tempting though it may be. However easily one imagines Treadwell as a "hanger-on type" — he was quite honest about this — he does seem to be emotionally scarred by violence, even if he is not connecting that violence to a historicized socio-political order (see Giddens 1994:229236). But being marked by human to human violence is merely one part of what motivated the eco-warrior.

One interesting aspect of Treadwell's character that I have been able to discern, more from his footage of himself rather than from his book, is that he often employs grammatical structures which hardly make sense; his thoughts take flight abruptly through unrelated topics. He rambles, repeating sentences as monologue fillers, I believe, when he is not sure what to say or how he wants to communicate next. And yet, he is half-aware of the splits in his thought-processes and his awkwardness with language, which I think is part of why he shoots some takes up to fifteen times, and why he often corrects his word choice while in mid-sentence.

Aside from his camera, I believe he feels very much under the lens, of the scientific and park community, as well as of the public. Such a complex character as Treadwell who has lived in New York and southern California during late capitalism — certainly not the same civilization as 19th century America—-deserves more comprehensive analysis. For this I will use the schizoanalysis offered by Gilles Deleuze and Félix Guattari, mainly because it posits the awareness that people are inevitably part of and dependent upon nature and that as a method of analyzing the schizophrenic (from figures such as Lenz to Americans such as Jack Kerouac), this method tends to merge psychoanalysis with what C. Wright Mills referred to as the "Sociological Imagination" ([1959] 2000) by way of the politicization of desire, a concept which Fredric Jameson has traced back to the philosophical work of that other great figure of German classicism, Friedrich Schiller (Jameson 1971:83-106). Treadwell is plagued by the manicdepression and paranoia of the subject who would be the product of what Deleuze and Guattari have termed "the despotic machine" ([1972] 1983:33), a remnant of an earlier historical epoch. Additionally, his ego has been shattered; his torn and twisted mind appears to represent various modes of social control (for Deleuze and Guattari, "territorialization") in seemingly kaleidoscopic formation, and at the same time the desire to break free from them (or "deterritorialization"). According to their analysis, some paranoid or repressed individuals go through a process in which they attempt to unscramble the codes of modernity, in order to become revolutionary, and it is at this point that paranoia and schizophrenia are able to be separated. Not all achieve such a breakthrough, however, without first suffering a breakdown (278). One possible point of inquiry might be why people such as Treadwell come to empathize with animals more than with the sufferings of politically manipulated people, and whether they unconsciously perceive animals as metaphors for such people. In one scene in his book, Treadwell records his hearing of a story in which "federal people" from Washington, D. C., who were petrified of bears, left Katmai National Park early. He conjectures that Katmai is much safer than Washington, D.C. (1997:76). What becomes apparent is that some bureaucrats need not concern themselves with what is animalistic to gain an understanding of how the 
will to power operates in society; meanwhile, some people voluntarily forfeit their status as political animals (in the Aristotelian sense) by trying to empathize with animals/nature, and remain politically powerless.

\subsection{Subjectivity and Indifference in Nature}

Before writing of Goethe's conception of nature and subjectivity two clarifications are in order. The first is that I am referring to the man's mature views. Of course, there was one incident in his youth, when, after a skirmish with death, he reacted to the sentimentalists of his own time, positing nature as "indifferent to human sufferings or sentiments" (Boyle 1991:128-129). After Goethe seriously took up the study of nature, he came to believe it to be of paramount importance that nature should draw men to the sublime, and that men of science must maintain a sense of awe in regard to the natural world. He believed that scientific knowledge "helps us mainly because it helps the wonder by which we are called to nature rather more intelligible..."(Goethe 1998:51). The second clarification admits that it is difficult to respect nature by believing it to be irrevocably subjective, and Goethe rejected this idea (Naydler 1996:91). Instead, he considered experiments as "inquiries into nature" (Magnus [1906] 1949:227). But he also realized a considerable barrier between man's ability to understand and the secrets which nature possessed of her internal order. As Goethe wrote in 1798: “...Nature understands no jesting; she is always true, always serious, always severe; she is always right, and the errors and faults are always those of the human being. The person incapable of appreciating her she despises, and only to the apt, the pure, and the true, does she resign herself, and reveal her secrets" (quoted in Naydler 1996:109). At the same time, he was able to see that much of what scientists might say about nature may reflect more about the scientists as people than about nature itself. Thus, while he conducted scientific study, he classified the different modes of contemplating nature, the lowest level consisting of the exploiters, or those who seek to use what nature offers for their own practical purposes (Magnus [1906] 1949:228-229).

Although Goethe's awe and respect for nature would come to be shared by Ralph Waldo Emerson on the western side of the Atlantic, for most of the modern era, the demands of market capitalism have had little patience for Goethe's conception as to how the study of nature should proceed, and scholars trained in the European continental tradition have offered the most trenchant critiques toward the exploitation of nature, or as members of the Frankfurt School Max Horkheimer and Theodor Adorno have termed it in The Dialectic of Enlightenment, the domination of nature (Beherrschung der Natur). The term "nature" here can seem somewhat ambivalent, since it may refer to a person's inner nature and at the same time to the external, natural environment. In the latter case, the "domination of nature" describes the process of appropriation of the earth's natural resources through and in the form of technology by "Kings no less than merchants" ([1947] 2002:2). Environmentalist scholars in North America have found this model of critique useful in their own studies of the human relation to their natural environment (see Leiss [1972] 1994; Worster 1986). Quite central to the inheritance of the Frankfurt School's concept of the domination of nature is its materialist emphasis on modes of production and its resistance against jettisoning the concept of the metanarrative (Worster 1990:1142-43). Readers will doubtless find my views for the most part aligned with this sort of critique.

But it is important to examine another side of environmental studies, represented most notably by historian William Cronon, which has emphasized the role of culture in the perception of nature (1983, 1991, [1995] 1996), and therefore the direction of the whole environmental movement. The lead essay in Cronon's edited volume Uncommon Ground: Rethinking the Human Place in Nature ([1995] 1996), titled The Trouble with Wilderness; or, Getting Back to the Wrong Nature, places the environmental movement in a historical context, not in any Marxist historical context (i.e., privileging means and modes of production) but rather in a historicized cultural context which emphasizes instead intellectual movements, or, the ideal rather than the material. Thus, Cronon: "Indeed, it is not too much to say that the modern environmental movement is itself a grandchild of romanticism and postfrontier ideology, which is why it is no accident that so much environmentalist discourse takes its bearings from the wilderness these intellectual movements helped create" (72). William Cronon buttresses his argument by examining and quoting those wild men of the nineteenth century, Henry David Thoreau and John Muir. One begins to see connections between Cronon's way of emphasizing the cultural and the extent to which nature can be considered as subjective, or mentally constructed, and the picture which Herzog has offered through the use of the wild man star of his documentary. As Herzog explained to interviewer Paul Cronin, "For me a true landscape is not just a representation of a desert or a forest. It shows an inner state of mind, literally inner landscapes ... This is my real connection to Caspar David Friedrich..." (2002:136).

While William Cronon argued that Uncommon Ground intended to reflexively question the environmental 
movement so that it would not proceed on intellectual foundations "that may ultimately prove unsustainable"(26), he met with strident opposition, especially in Wild Earth magazine.[14] One article by Bill Willers, "The Trouble with Cronon," accused him of having "dealt quite a blow to the Environmental Movement." Cronon, as I believe they quite correctly saw, had formulated his argument while failing to take the possibility of anti-environmental machinations into account. As Cronon writes in the 1996 edition, "These essays were written just before a powerful conservative resurgence produced by a Republican-dominated Congress that quickly distinguished itself as the most hostile toward environmental protection in all of U.S. history." Thereafter, he remarks that the counter-revolution against environmentalism had met with more resistance than its supporters had hoped (19). On the other hand Herzog offers two positions about his filmmaking, which are both incompatible, neither one being independently tenable. Concerning the environment, he says to Paul Cronin, "We comprehend ... that nuclear power is a real danger for mankind, that overcrowding of the planet is the greatest of all. We have understood that the destruction of the environment is another enormous danger." However, he also claims that "the lack of adequate imagery is a danger of the same magnitude" (2002:66). One may suppose however, that Herzog's belief that it is possible for film to remain in a realm independent from the political could lead him to make this last claim: he states that he has never been into using the medium of film as a political tool (56), and this strikes me as being hauntingly naïve. The dismal and yet powerful statement that the common denominators of the universe are "chaos, hostility, and murder" is antithetical to the hope for sustainable society, and seems to condone the reversion of western society back to a stage of life being brutish, short, and nasty (as described in Hobbes [1651] 1973:98-102), while the continued domination of nature insures that technological development plays an ever increasing role therein.

While one watches Treadwell in his mood swings, one may notice that Herzog seems to represent himself and his own views in quite polarized reaction to those of Treadwell, as though in contrast to Treadwell's beautiful seemliness of the dream world, he is presenting the horrifying and intoxicated reality which underlies Treadwell's illusory conception of nature. In the documentary In the Edges, which depicts the making of the soundtrack for Grizzly Man, Herzog is seen watching a clip of Treadwell swimming with a bear, petting the creature from behind. Seeming to echo the thoughts of Van Daele, Herzog comments: "You see, it looks like complete harmony of man and beast, like him in unison with nature. We believe things are alright and they are not when you find the dark menace in it" (2005). This dynamic, in its illusion-reality orientation, resembles Nietzsche's juxtaposition of the Apollonian and Dionysian (Nietzsche [1872] 1993).[15] But the director's stark view on nature made itself manifest long ago, during the filming of his Fitzcarraldo. Todd Gitlin comments in a review over the disastrous consequences of Herzog filming in South America, and discussing Les Blank's documentary Burden of Dreams (which covers the turbulent events), writes, “...Herzog fulminates against the very nature he went half-way around the world to find. Just as the Romantic identifies with nature's unspoiled qualities, its wildness or peace ... Herzog inverts the image, and some decidedly unpretty themes leap out of the German past...” (1983:51). He then quotes Herzog at length:

I see fornication and asphyxiation and choking and growing for survival and growing and rotting. The trees here are in misery. The birds here are in misery - they don't sing, they just shriek in pain ... We are cursed for what we are doing here! It is a land that God, if he exists, has created in anger! There is no order here, no harmony in the universe! The only harmony is of overwhelming, collective murder! It is a vile, base obscenity! (ellipses mine, quoted in Gitlin 1983:51-52)

Whether Treadwell reminded Herzog of a former version of the film maker himself is something only Herzog can say. However, just as Herzog cannot use the camera in a way that is non-political, he also cannot discuss nature in a way that is non-philosophical. I am reminded of a conjecture offered by William James, whose tendency toward "middle-of-the-roadism" which was so important for pragmatism led him to the juxtaposition of exorbitant polar positions (West 1993:57), "The Tender-Minded" and "The Tough-Minded". The former includes characteristics such as Idealistic, Optimistic, Religious, Free-willist, while the latter by contrast is Materialistic, Pessimistic, Irreligious, Fatalistic (James [1907] 1968:22). While these traits do not perfectly fit the eco-warrior and the Bavarian director respectively, one sees where Herzog could have developed a more balanced view.

\section{Toward a Conclusion of Meaning}

The decision to narrate events assigns meaning to them (Jameson [1961] 1984). The question of what kind of meaning remains, however. In my view, Herzog could have extended a deeper meaning to the story of Treadwell had he proceeded further in his thought, either toward the "middle-of-the-roadism" described above, or perhaps 
better, toward any sort of synthesis (Aufhebung). Whereas he might have assigned a higher form of meaning to the events of Treadwell's life by dialectical thought, he was merely antithetical. While Herzog sometimes showed footage from high altitudes, which served in some respect to grant some authority to certain statements he made, I do not see him as reaching any higher position: he may have moved his position on a horizon, but I have not been able to locate verticality or transcendence of any sort. As troubled as Treadwell was, Herzog might have considered that his subject's lack of maturation did not occur within a social vacuum, or what possible options might have been open to him had he learned to channel his energies in a more constructive way before arriving in Long Beach. He might have considered that a conception of the natural cycle as consisting of predators can be assimilated into a conception of nature that allows for a certain amount of dissidence between the species within an overall balance that is somewhat harmonious, in weather patterns, the food chain, and so forth. In a time of climate change, gene manipulation, and the basest exploitation of the earth's natural resources, this should be considered imperative.

Tangentially, Herzog also shortchanges what the German tradition has to offer. By the cant in his narration of the life and death of a real figure in Treadwell, he serves to "superegoize" not only the story, but also the viewing audience (Deleuze and Guattari [1972] 1983:134). As a judge of character, Herzog appears to have learned from old Goethe, even though he is not as harsh. Yet, the attempt to practice Goethe's ideal for character might have worked quite well in a society which had adopted Goethe's conception of the human relationship with nature. But throughout the 19th and much of the 20th century, Goethe's conception to nature has hardly received adherence. It may be time to begin ethically exploring that which experience as a means to understanding entails, while otherwise attempting to absorb and assimilate the abiding wisdom in much of Goethe's insight into a pragmatic theory of daily political participation. And while Herzog may have intended to close the discussion by stating that the arguments as to how wrong or right Treadwell was disappear into a fog, I imagine that his film will only strengthen debate, especially during an era in which the mass media derives infotainment from characters such as Treadwell, Cindy Sheehan, and Britney Spears, who are willing to take their personal pain forward, acting out in front of the public and crying for help.

\section{Endnotes}

1. My thanks to Ben Agger, Jennifer William, Lynn MilesMorillo and John Herda for their critical commentary; however, all claims are my own.

2. See Jay Antani, in the 2006 Perihelion Journal. (http:// www.perihelionjournal.com/reviews/GrizzlyMan.html, accessed Nov. 30, 2007)

3. See "Review by Ross Anthony". (http://rossanthony. com/G/grizzlyman.shtml, accessed Nov. 30, 2007)

4. This is a problematic aspect for Herzog, presenting such an artistic documentary to an American audience: many Americans have seen Treadwell being interviewed on television during the late 1990 s, when he was at the height of his celebrity. Herzog has chosen a subject matter for a documentary that has been the subject of books by other authors, who perhaps do not dramatize the way Herzog does. While some may consider Herzog to be artistic in his representation of Treadwell, others may find there to be a certain amount of cant in Herzog's representation.

\section{See Mike Lapinski, p. 145.}

6. I find that Egli's comment shows deeper insight into Treadwell than Herzog's representation. Herzog very often focuses on Treadwell's wanting to become a bear, arguing that Treadwell makes a clear distinction between the people's world and that of the bears. Egli's comment shows that Treadwell also wanted the bears to become human. In his book Among Grizzlies, he refers to one bear as having "a maniacal glint in his eye" (Treadwell and Palovak 1997:61) and to others as having "passionate sex" $(66,80,85)$. He also dreams of taking bears with him to an Italian restaurant in San Francisco where one bear would "inhale thirty-three orders of hearty lasagne," while the staff would toss gourmet pizzas into another's mouth (99).

7. In the documentary In the Edges: The Grizzly Man Session (Herzog 2005), Herzog carries on the following discourse in regard to the music played in the background during this particular scene: "This is not country and western music, you see, that's for the crackers, that's for the middle class America and so, but this is for the cowboys. That song is for the Rodeo riders, that's where the real men [sic]!"

8. Refer back to note 6 .

9. Here Herzog is referring to Klaus Kinski, the actor who played the lead role in his films Aguirre: Der Zorn Gottes, Woyzeck, and Cobra Verde, and whom Herzog once called a "genius" (see Cronin 2002:87-93, 139, 155-61, 208-210). 
10. See Marrit Ingman's interview, "Discord and Ecstacy: Werner Herzog on 'Grizzly Man.” (http:// www.austinchronicle.com/gyrobase/Issue/ story?oid=oid\%3A285426, accessed Nov. 30, 2007)

11. See Gerhard P. Knapp's entry on Georg Büchner in The Literary Encyclopedia. (http://www.litencyc.com/ php/speople.php?rec $=$ true $\& U I D=5188$, accessed Jan. 15, 2008)

12. Treadwell at one point does contend, in a manner which one imagines Nietzsche might applaud, “Fortunately, unlike humans, brown grizzlies don't hold grudges" (Treadwell and Palovak 1997:62).

13. See Jennifer Marston William's entry on Monika
Maron in The Literary Encyclopedia. (http://www. litencyc.com/php/speople.php? rec $=$ true $\& U I D=5699$, accessed Jan. 15, 2008)

14. See Wild Earth, Winter 1996/1997.

15. As I see it, Nietzsche's initial conception of aesthetics has been quite seminal for Herzog's conception of man's relation to nature. Writing over Nietzsche's aesthetic paradigm, Allan Megill comments parenthetically: "One notes the absence here of any attempt to canvass possibilities intermediate between $\mathrm{X}$ and $\mathrm{Y}$, between 'cloud cuckoo land' and 'the essence of things"” (1985:51).

\section{References}

Bachman, Gideon. 1977. “The Man on the Volcano: A Portrait of Werner Herzog.” Film Quarterly Vol. 31, No. 1:2-10.

Boyle, Nicolas. 1991. Goethe: The Poet and the Age, Vol. 1, The Poetry of Desire (1749-1790). Oxford:Clarendon Press.

Büchner, Georg. 1986. Complete Works and Letters. New York:Continuum.

Cronin, Paul. 2002. Herzog on Herzog. New York:Faber and Faber, Inc.

Cronon, William. 1983. Changes in the Land: Indians, Colonists, and the Ecology of New England. New York:Hill and Wang.

1991. Nature's Metropolis: Chicago and the Great West. New York:W. W. Norton and Company.

,ed. [1995] 1996. Uncommon Ground: Rethinking the Human Place in Nature. New York:W. W. Norton \& Company.

Deleuze, Gilles and Félix Guattari. [1972] 1983. Anti-Oedipus: Capitalism and Schizophrenia. Minneapolis:University of Minnesota Press.

Freud, Sigmund. [1940] 1969. An Outline of Psycho-Analysis. New York:W. W. Norton and Company.

Gay, Peter. 1988. Freud: A Life for Our Times. New York:W. W. Norton \& Company.

Giddens, Anthony. 1994. Beyond Left and Right: The Future of Radical Politics. Stanford, California:Stanford University Press.

Gitlin, Todd. 1983. "Review: Untitled.” Film Quarterly Vol. 37, No. 2:50-54.

Goethe, Johann Wolfgang von. 1998. Maxims and Reflections. London:Penguin Books.

Harvey, David. 2005. A Brief History of Neoliberalism.
Oxford:Oxford University Press.
Herzog, Werner. [1976] 2000. Woyzeck. [DVD] Anchor Bay Entertainment.

2005. Grizzly Man. [DVD] Lions Gate Home Entertainment.

Horkheimer, Max and Theodor Adorno. [1944] 2002. Dialectic of Enlightenment. New York:Herder and Herder.

Hobbes, Thomas. [1651] 1973. Leviathan: Or the Matter, Form and Power of a Commonwealth Ecclesiasticall and Civil. New York:Collier Books.

James, William. [1907] 1968. Pragmatism. New York:Meridian Books.

Jameson, Fredric. [1961] 1984. Sartre: The Origins of a Style. New York:Columbia University Press.

1971. Marxism and Form: Twentieth Century Dialectical Theories of Literature. Princeton, N.J.:Princeton University Press.

Jancke, Gerhard. 1979. Georg Büchner: Genese und Aktualität seines Werkes. Regensburg:Athenäum Verlag.

Lapinski, Mike. 2005. Death in the Grizzly Maze: The Timothy Treadwell Story. Guilford, Conn.: Falcon.

Larsen, Svend Erik. 1988. "Die Macht der Machtlosen. Über Lenz und Woyzeck." Pp. 176-194 in Georg Büchner im interkulturellen Dialog, edited by Klaus Bohnen and ErnstUllrich Pinkert. München:Wilhelm Fink Verlag.

Leiss, William. [1972] 1994. The Domination of Nature. London:McGill-Queen's University

Press. Magnus, Rudolf. [1906] 1949. Goethe as a Scientist. New York:Henry Schuman.

Maron, Monika. 1993. Silent Close No. 6. London:Readers International 
Mayer, Hans. [1946] 1974. Georg Büchner und seine Zeit. Frankfurt am Main:Suhrkamp.

Megill, Allan. 1985. Prophets of Extremity: Nietzsche, Heidegger, Foucault, Derrida. Los Angeles:University of California Press.

Mills, C. Wright. [1959] 2000. The Sociological Imagination. New York:Oxford University Press.

Naydler, Jeremy. 1996. Goethe on Science: An Anthology of Goethe's Scientific Writings. Edinburgh:Floris Books.

Nietzsche, Friedrich. [1872] 1993. The Birth of Tragedy. London:Penguin Books.

[1874] 1980. On the Advantage and Disadvantage of History for Life. Indianapolis:Hackett Publishing, Inc.

1913. The Will to Power: An Attempted Transvaluation of all Values, Vol. II. Edinburgh:T.N. Foulis.

Prager, Brad. 2007. The Cinema of Werner Herzog: Aesthetic Ecstasy and Truth. London:Wallflower Press.
Treadwell, Timothy and Jewel Palovak. 1997. Among Grizzlies: Living with Wild Bears in Alaska. New York: Ballantine Books.

Trunz, Erich, ed. 1998. Goethe Faust: Der Tragödie erster und zweiter Teil Urfaust. München:C. H. Beck Verlag.

West, Cornel. 1993. The American Evasion of Philosophy: A Genealogy of Pragmatism. Madison:University of Wisconsin Press.

Wittkowski, Wolfgang. 1978. Georg Büchner: Persönlichkeit. Weltbild. Werk. Heidelberg:Carl Winter Universitätsverlag.

Worster, Donald. [1986] 1992. Rivers of Empire: Water, Aridity, and the Growth of the American West. Oxford:Oxford University Press.

. 1990. "Seeing Beyond Culture." Journal of American History 76:1142-1147. 
